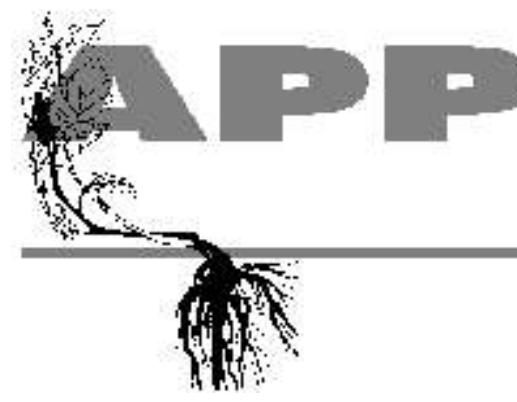

\title{
Evaluating the Madeiran wheat germplasm for aluminum resistance using aluminium-induced callose formation in root apices as a marker
}

\author{
Teresa M. M. dos Santos ${ }^{1}$, Jan J. Ślaski ${ }^{2,5}$, Miguel Â. A. Pinheiro de Carvalho ${ }^{1}$, Gregory J. Taylor ${ }^{3}$, \\ Maria R. Clemente Vieira ${ }^{4}$. \\ ${ }^{1}$ Centre of Macaronesian Studies, University of Madeira, 9000-390 Funchal, Portugal \\ 2 Environmental Technologies, Alberta Research Council, Vegreville, Alberta, T9C 1T4, Canada \\ ${ }^{3}$ Dept. of Biological Sciences, University of Alberta, T6G 2E9, Canada \\ ${ }^{4}$ Institute of Botany, University of Coimbra, 3000 Coimbra, Portugal \\ 5 corresponding author: e-mail: slaski@arc.ab.ca
}

Key words: aluminum, callose, Madeira, resistance, root elongation, wheat

\begin{abstract}
Aluminum ( $\mathrm{Al}$ ) resistance of 57 Madeiran wheat cultivars was evaluated using callose content in root tips and root elongation as markers. Al induced callose formation was a very sensitive indicator of $\mathrm{Al}$ damage detecting wide range of genotypic differences existing in the Madeiran wheat germplasm. A weak, yet positive correlation $\left(\mathrm{R}^{2}=0.285, \mathrm{P}<0.05\right)$ between callose content and root elongation was found.
\end{abstract}

\section{Introduction}

Toxicity of aluminum (Al) is considered to be a major growth and yield limiting factor on mineral soils with pHs below 5.0 (Anioł 1990, Foy 1992). Soil acidity is a severe agricultural problem affecting about $40 \%$ of the world's arable land (Haug 1984), including north-central part of continental Portugal. Under acidic conditions, monomeric aluminum species are released to soil solution from soil minerals and from polycationic, non-toxic aluminum complexes that exist at neutral $\mathrm{pH}$. Once in soil solution, soluble aluminum ions can be taken up by roots and consequently adversely affect plant growth. The first observable symptom of aluminum toxicity is reduction of root growth (Foy 1992). The ability of roots to continue elongation in the presence of $\mathrm{Al}$ ions in nutrient solution is often used to evaluate aluminum resistance of crops (Foy 1992). Using root elongation tests facilitated by the eriochrome cyanine staining method, we have recently found that several old wheat cultivars from the Atlantic Island of Madeira exhibited enhanced resistance to $\mathrm{Al}$ compared to a cultivar commonly used as a standard for $\mathrm{Al}$ resistance (Pinheiro de Carvalho et al. 2003). The history of wheat cultivation on the Island of Madeira began in the fifteenth century, when the first varieties were introduced from the Portuguese mainland followed by major introductions of wheat from the Canary Islands, Azores, North Africa and Southern and Northern Europe (Pinheiro de Carvalho et al. 2003). Cultivars adapted to acid soils predominant on the island were retained by farmers for cultivation. For decades, local farmers who operated on small plots, often located in remote and isolated mountain val- 
leys have been using their own stocks of wheat seeds that were apparently introduced to the island centuries ago. Recently, we were able to collect and to preserve Madeiran wheat germplasm from extinction due to low profitability of traditional farming methods. These cultivars could eventually serve as donors of genes controlling $\mathrm{Al}$ resistance in breeding programs around the world provided that their superior resistance is convincingly validated using sensitive, widely accepted screening methods.

In recent years, Al-induced callose deposition in root apical meristems has been proposed as a rapid physiological marker for the assessment of Al toxicity even before inhibition of root elongation could be measured (Wissemeier et al. 1987, Zhang et al. 1994, Wissemeier and Horst 1995). It has been demonstrated that this sensitive technique allows for measurement of Al-triggered inhibition of maize root growth as early as 30-90 minutes after exposure of plants to $\mathrm{Al}$ in nutrient solution (Llugany et al. 1994). Callose formation has been successfully used as an indicator of genotypic differences in response to $\mathrm{Al}$ in nutrient solution in wheat and maize cultivars (Ślaski et al. 1996, Horst et al. 1997).

This communication presents our efforts towards the evaluation of the Madeiran wheat germplasm for $\mathrm{Al}$ resistance using callose formation and root elongation as parameters of $\mathrm{Al}$ injury.

\section{Material and Methods}

Experiments were carried out using 57 Madeiran wheat cultivars obtained from the ISOPlexis Germplasm Bank at the University of Madeira, Funchal (http://www.uma.pt/Investigacao/Ccbg/ /swebs/germoplasma/index.html). Two cultivars, Maringa (from Brazil) and Katepwa (from Canada) were used as standards for $\mathrm{Al}$ resistance and sensitivity, respectively. Seeds were surface sterilized in $5 \%$ sodium hypochlorite and germinated overnight at $25{ }^{\circ} \mathrm{C}$. Three sets of twenty sprouted seeds of each genotype were placed on a raft floating on a surface of aerated nutrient solution containing (in

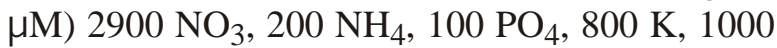
$\mathrm{Ca}, 300 \mathrm{Mg}, 101, \mathrm{SO}_{4}, 34 \mathrm{Cl}, 60 \mathrm{Na}, 10 \mathrm{Fe}, 6 \mathrm{~B}, 2$ $\mathrm{Mn}, 0.15 \mathrm{Cu}, 0.5 \mathrm{Zn}, 0.1 \mathrm{Mo}$ and 10 EDTA (Ślaski et al. 1996) and grown for 4 days in a growth chamber at $23^{\circ} \mathrm{C}$. For $\mathrm{Al}$ exposure, seedlings were transferred to fresh nutrient solution containing (in $\mu \mathrm{M}$ ) $2900 \mathrm{NO}_{3}{ }^{-}, 300 \mathrm{NH}_{4}{ }^{+}, 1000 \mathrm{Ca}^{2+}$, and $300 \mathrm{Mg}^{2+}$, with 100 or $200 \mu \mathrm{M}$ Al supplemented in form of $\mathrm{AlCl}_{3} \times 6 \mathrm{H}_{2} \mathrm{O}$ for $72 \mathrm{~h}$. Aluminium activities in nutrient solution were calculated using the program GEOCHEM-PC version 2.0. Speciation analysis predicted that the free activity of $\mathrm{Al}^{3+}$ was $1.59 \times$ $10^{-5} \mathrm{M}$ and $1.58 \times 10^{-5} \mathrm{M}$ for the 100 and $200 \mu \mathrm{M}$ treatment solution, respectively. The two solutions differ dramatically in the amounts of precipitated hydroxyl form of Al: $6.47 \times 10^{-5} \mathrm{~mol} \mathrm{~L}^{-1}$ and $1.65 \times$ $10^{-4} \mathrm{~mol} \mathrm{~L}^{-1}$ for 100 and $200 \mu \mathrm{M}$ solution, respectively (Pinheiro de Carvalho et al. 2003). Aluminium solution was replaced daily to minimize $\mathrm{pH}$ fluctuation and $\mathrm{Al}$ depletion. In all treatments, the $\mathrm{pH}$ of nutrient solutions was measured every 12 $\mathrm{h}$ and adjusted to 4.3 with $0.1 \mathrm{~N} \mathrm{HCl}$, if necessary. The length of the longest root of each seedling from one of the three seed sets was measured after 0,24 , 48 , and $72 \mathrm{~h}$ of Al treatment. The increase in length of roots during $72 \mathrm{~h}$ was used to rank the Madeiran wheat cultivars to ensure full expression of genotypical differences in response to $\mathrm{Al}$ exposure.

$1,3-\beta$-D-glucan (callose) content was measured after $24 \mathrm{~h}$ exposure to $\mathrm{Al}$ using the method described by Zhang et al. (1994). Thirty freshly excised root tips (5 mm long) originated from 20 seedlings taken from the remaining two seed sets were placed in microcentrifuge tubes containing $95 \%$ ethanol for at least $1 \mathrm{~h}$. The alcohol was subsequently decanted and $200 \mu \mathrm{l}$ of $1 \mathrm{M} \mathrm{NaOH}$ was added to the tubes. The root tissue was ground in tubes for $20 \mathrm{~s}$ using a Teflon pestle mounted to an electric drill. To avoid cross contamination, the pestle was rinsed with 800 $\mu \mathrm{l}$ of $1 \mathrm{M} \mathrm{NaOH}$ after each grinding. Samples were placed in a water bath at $80{ }^{\circ} \mathrm{C}$ for $15 \mathrm{~min}$ to solubilize callose and centrifuged at $15000 \mathrm{~g}$ for 4 min. The supernatant $(400 \mu \mathrm{l})$ was incubated with $800 \mu 10.1 \%$ aniline blue, $420 \mu \mathrm{l} 1 \mathrm{M} \mathrm{HCl}$, and 1180 $\mu l$ glycine- $\mathrm{NaOH}$ buffer ( $\mathrm{pH} 9.5$ ) for $20 \mathrm{~min}$ at 50 ${ }^{\circ} \mathrm{C}$ and for $30 \mathrm{~min}$ at room temperature. Callose content was estimated using an Aminco-Bowman spectrofluorometer with excitation at $398 \mathrm{~nm}$ and emission at $495 \mathrm{~nm}$. Pachyman (Calbiochem, La Jolla, CA, USA) was used as an external standard 
and callose content was expressed as mg Pachyman equivalent (PE) per g root fresh weight.

All experiments were run in two duplicates for each experimental variant. Experimental results represent the mean values of these duplicates. The experimental standard deviation of performed measurements was lower than $15 \%$. Data were analysed using SAS system for Windows version 8.0 (SAS Institute Cary, NC) software. A one way analysis of variance (ANOVA) with mean separation by the Fisher's Least Significant Difference (LSD) was performed to study the differences between cultivars exposed to Al. Pearson correlation between root elongation and callose content at 100 and $200 \mu \mathrm{M}$ was determined, as well as their statistical significance. Correlations were considered significant at $\mathrm{P}$ values below 0.05 . The statistical analyses and data treatment were preformed using software program Excel and SPSS 10.0 for Windows.

\section{Results and Discussion}

Induction of callose formation in root tips triggered by Al varied among the Madeiran wheat genotypes. Callose content in the $\mathrm{Al}$ treated roots ranged from 0.4 to $4.8 \mathrm{mg}$ Pachyman equivalent per $\mathrm{g}$ fresh weight in resistant and sensitive genotypes, respectively (Fig. 1). Eight out of 57 genotypes tested at $100 \mu \mathrm{M} \mathrm{Al}$ and 2 genotypes tested at $200 \mu \mathrm{M} \mathrm{Al}$ formed less callose than cv. Maringa, a recognized standard for $\mathrm{Al}$ resistance. On the other hand, only 6 genotypes exposed to $200 \mu \mathrm{M} \mathrm{Al}$ accumulated more callose than the Al-sensitive standard cv. Katepwa. These results may indicate that the Madeiran germplasm could be a valuable source of genes controlling $\mathrm{Al}$ resistance in wheat. In general, the amounts of callose deposition at $100 \mu \mathrm{M}$ $\mathrm{Al}$ were correlated $\left(\mathrm{R}^{2}=0.433, \mathrm{P}<0.05\right)$ with those found at $200 \mu \mathrm{M} \mathrm{Al}$ (Fig. 1, inset). A detailed analysis of callose content in root tips of the Madeiran wheat germplasm revealed an interesting difference in response to $\mathrm{Al}$ treatment with 100 and 200 $\mu \mathrm{M}$ Al. As expected, the genotypes classified as Al-resistant (low callose content) at $100 \mu \mathrm{M} \mathrm{Al}$ formed more callose when exposed to $200 \mu \mathrm{M} \mathrm{Al}$. Such findings have been reported previously (Llugany et al. 1994, Ślaski et al. 1996, Horst et al.
1997). An opposite trend, however, was observed among Al-sensitive genotypes where less callose was deposited in roots treated with $200 \mu \mathrm{M}$ than $100 \mu \mathrm{M} \mathrm{Al}$ (Fig. 1). We could speculate that this phenomenon might suggest a complexity in mechanisms controlling $\mathrm{Al}$ resistance in wheat. Based on studies using ditelosomic lines of wheat, Anioł (1990) concluded that several major genes, minor modifying genes and genes controlling suppression of $\mathrm{Al}$ resistance can be identified in hexaploid wheat. He also suggested that expression of some genes from the $\mathrm{D}$ genome could be triggered only by higher Al concentrations in the medium. Further studies of the Madeiran wheat germplasm are currently underway to verify this hypothesis. In previous studies, we evaluated several Madeiran wheat genotypes for $\mathrm{Al}$ resistance using the eriochrome cyanine test (Pinheiro de Carvalho et al. 2003). We were able to identify two major types of response to $\mathrm{Al}$ stress, as genotypes were either Al-resistant or Al-sensitive both at 100 and $200 \mu \mathrm{M} \mathrm{Al}$, while only very few genotypes were classified as intermediate. Using the callose test as a marker of $\mathrm{Al}$ resistance no distinct type of response could be identified but a gradual transition from very resistant to extremely sensitive genotypes was observed (Fig. 1). Again, this may indicate that the callose test was more sensitive that the eriochrome cyanine one and thus in the present study we managed to document a whole spectrum of responses of the Madeiran germplasm to $\mathrm{Al}$ treatment. Interestingly, the callose test has identified ISOP 0076 line as the most Al-resistant genotype, while this line ranked only as the $5^{\text {th }}$ most resistant according to the eriochrome cyanine test. Callose deposition in root apices of the Madeiran wheats correlated with the Al induced inhibition of root elongation $\left(\mathrm{R}^{2}=0.285, \mathrm{P}<0.05\right)$ (Fig. 2, inset). The pattern of response to lower and higher $\mathrm{Al}$ concentrations among the sensitive and the resistant genotypes resembled that observed in callose deposition. Genotypes highly resistant to $\mathrm{Al}$ at concentration of 100 $\mu \mathrm{M}$ appeared to be substantially (over $50 \%$ ) more sensitive to $\mathrm{Al}$ at concentration of $200 \mu \mathrm{M}$ while the genotypes classified as extremely Al-sensitive at $100 \mu \mathrm{M}$ Al exhibited slightly better performance at $200 \mu \mathrm{M} \mathrm{Al}$ (Fig. 2). In conclusion, we found that $\mathrm{Al}$ induced callose deposition in root tips was a sensitive and fast marker evaluating $\mathrm{Al}$ resistance in the 


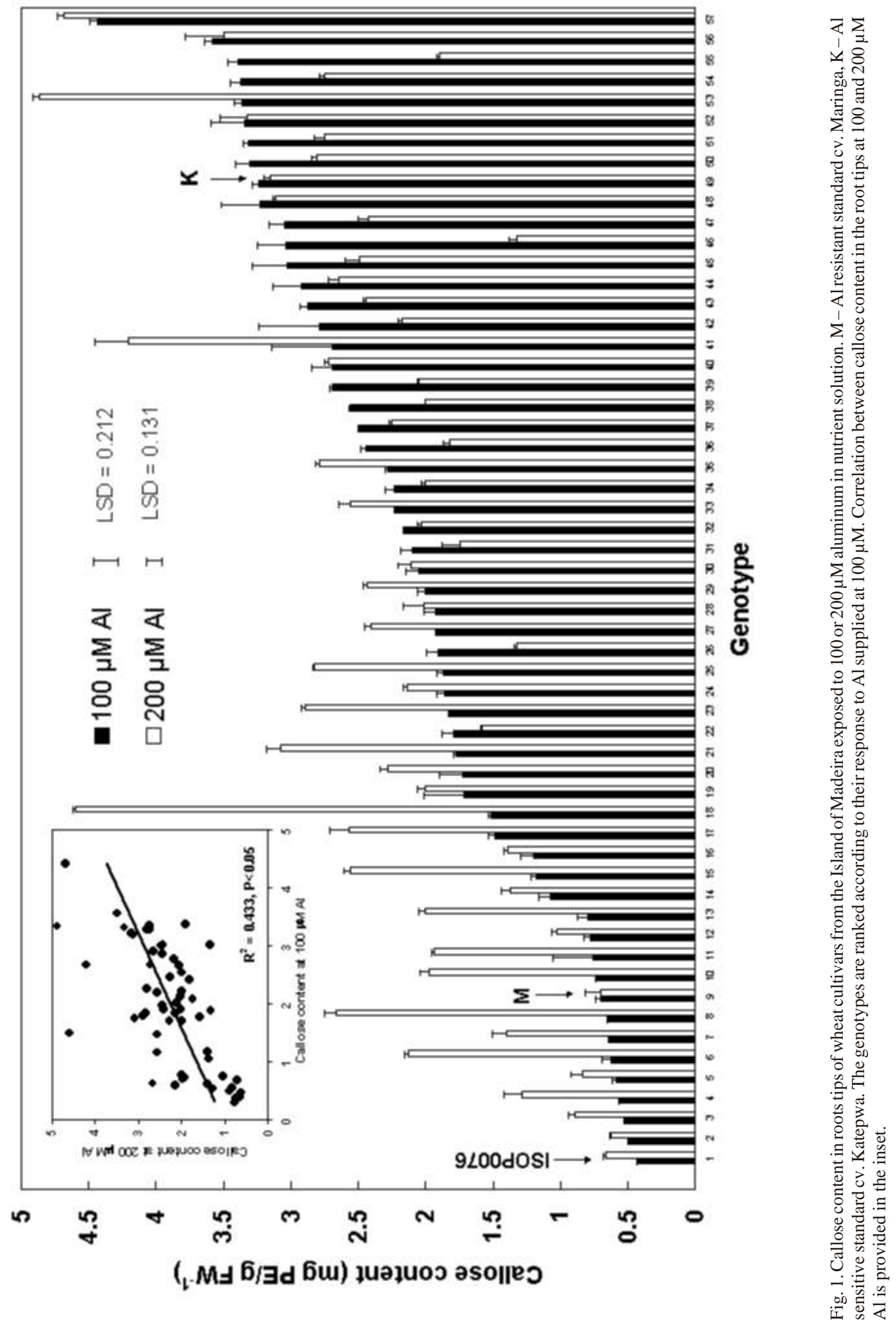



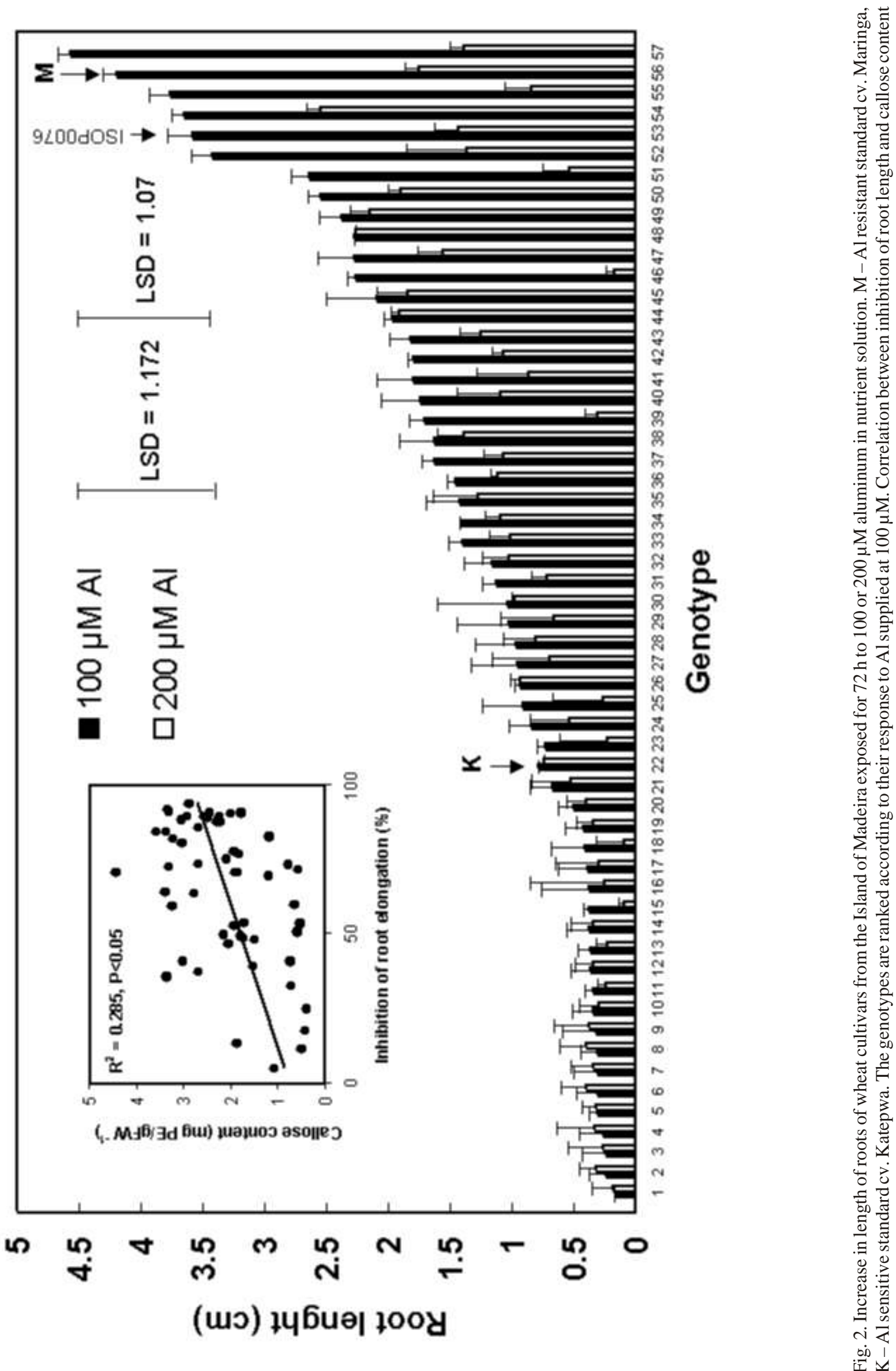
Madeiran wheat germplasm. We were able to detect very sensitive genotypes as early as after $6 \mathrm{~h}$ of exposure to $\mathrm{Al}$ (data not shown). The callose test appeared to be superior to the elongation test since it allowed us to overcome the high genotypical variability frequently affecting the reliability of measurements of root elongation at the seedling stage.

\section{Acknowledgements}

Portuguese Foundation for the Science and Technology (FCT) has sponsored this work through the Centre of Macaronesian Studies (CEM) and the project POCTI/ 35003/ AGR/ 2000. The authors are also grateful to the Madeiran Centre of Science and Technology (CITMA) for financial support. Acknowledgements are due to Dr. Andrzej Anioł for valuable advice during preparation of this manuscript and to Dr. Anthony Anyia for his help with statistical analyses.

\section{References}

Anioł A. 1990. Genetics of tolerance to aluminium in wheat (Triticum aestivum L. Thell). Plant and Soil 123: 223-227.

Foy C. D. 1992. Soil chemical factors limiting plant root growth. In: Steward, B. A., (Ed.): Advances in Soil Science. Vol. 9. pp. 97-149. Springer Verlag, New York.

Haug A. 1984. Molecular aspects of aluminum toxicity. CRC Crit. Rev. Plant Sci. 1: 345-374.

Horst W. J., Puschel A.-K. and Schmohl N. 1997. Induction of callose formation is a sensitive marker for genotypic aluminium sensitivity in maize. Plant and Soil 192: 23-30.

Llugany M., Massot N., Wissemeier A. H., Poschenreider C., Horst W. J., Barcelo J. 1994. Aluminium tolerance of maize cultivars as assessed by callose production and root elongation. Z. Pflanzenernahr. Bodenk. 157: 447-451.

Pinheiro de Carvalho M. A. A., Ślaski J. J., Dos Santos T. M., Ganança F. T., Abreu I., Taylor G. J., Clemente Vieira M. R., Popova T. N., Franco E. 2003. Identification of aluminium resistant genotypes among Madeiran regional wheats. Commun. Soil Sci. Plant Anal. 34: 2973-2985.

Pinheiro de Carvalho M. Â. A, Ślaski J. J., Abreu I., Ganança F. T., dos Santos T. M. M., Freita L., Clemente Vieira M. R., Nunes A., Antunes A., Taylor G. J. 2004. Factors contributing to the development of aluminium resistance in the Madeiran maize germplasm. J. Plant Nutr. Soil Sci. 167: 93-98.

Ślaski J. J., Zhang G., Basu U., Stephens J. L., Taylor G. J. 1996. Aluminum tolerance in wheat (Triticum aestivum) is associated with rapid, Al-induced changes in activities of glucose-6-phosphate dehydrogenase and 6-phosphogluconate dehydrogenase in root apices. Physiol. Plant. 98: 477-484.

Wissemeier A. H., Horst W. J. 1995. Effect of calcium supply on aluminum-induced callose formation, its distribution and persistence in roots of (Glycine $\max \mathrm{L}$.) merr.). J. Plant Physiol. 145: 470-476.

Wissemeier A. H., Kotz F., Horst W. J. 1987. Aluminum induced callose synthesis in roots of soybean (Glycine max L.). J. Plant Physiol. 129: 487-492.

Zhang G., J. Hoddinot, Taylor G. J. 1994. Characterization of 1,3 $\beta$-D-glucan (callose) synthesis in roots of Triticum aestivum in response to aluminum toxicity. J. Plant Physiol. 144: 229-234.

Received October 22, 2004; accepted February 10, 2005 edited by W. Horst 